\title{
Preparation and characterization of magnetic nickel nanoparticles by chemical reduction reaction
}

\author{
Saad H. Ammar ${ }^{*}$, Natheer Nori Ismail, Marwa F. Abdul Jabbar \\ ${ }^{*}$ Chemical Engineering Department, Al-Nahrain University \\ Corresponding Author E-mail: saad cheminet@yahoo.com
}

\begin{abstract}
$\underline{\text { Abstract }}$
The efficiency of many of conversion-processes in petroleum and industrial improves upon application of materials with the nanosized scale dimension, which is caused by enhancements and advances of improved properties as the particle size decreases. Nickel nanoparticles has numerous applications in petroleum industry with its own catalytic in additional to the magnetic properties. In this study, high purity nanosized magnetic nickel particles has been effectively prepared by chemical reduction of nickel chloride using hydrazine hydrate as reducing agent in aqueous solutions containing ethylene glycol and water and using polyvinylpyrrolidone (PVP) as anti-agglomeration agent. Nanosized Ni particles samples with different hydrazine to nickel chloride mole ratios and PVP to nickel chloride ratios were obtained at constant temperature of $80{ }^{\circ} \mathrm{C}$.

The morphology and structural properties of the produced magnetic nickel nanoparticles were characterized by powder XRD and AFM methods. XRD study revealed that the prepared nanoparticles were pure nickel nanoparticles without considerable oxides or other impurity phases. AFM test revealed that all prepared Ni nanoparticles was in nano scale, it was stated that Ni nanoparticles size was very affected by the hydrazine/nickel mole ratio. Experimental results showed that particle size decreases from $94.35 \mathrm{~nm}$ to $71.48 \mathrm{~nm}$ when increases the $\left[\mathrm{N}_{2} \mathrm{H}_{4}\right] /\left[\mathrm{Ni}^{2+}\right]$ molar ratio from $15: 1$ to $45: 1$.
\end{abstract}




\section{Introduction}

Metal such as iron, copper, nickel and zinc nanoparticles (NPs) have abundant attention in the recent years due to their distinctive physical and chemical properties and possible applications in many potentially fruitful applications such as catalytic reactions, magnetic material, microelectronics, optoelectronics, photo catalysis, information storage, sensors and among others [1]. Among various metal nanoparticles, nickel nanoparticles are one of the important materials for advanced technology due to their magnetic, catalytic and conductive properties and therefore widely applied in daily life [2].

Nickel nanoparticles have attracted abundant care in many industrial and petroleum refining applications such as oxidative dehydrogenation of alkanes, desulfurization of petroleum fuels and Fisher-Tropsch Synthesis due to their unique structure and surface properties [3].

There are various synthetic approaches have been proposed to produce Ni NPs for example spray pyrolysis, micro-emulsion, reversed micelles method, electrochemical method, laser driven aerosol, chemical vapor deposition and chemical reduction method. Most of these methods suffer from disadvantages [4]. Chemical-reduction technique in organic solvent or aqueous media has been examined extensively because of its improved abilities for regulatory structure, size and shape $[3,5]$.

Chemical reduction method is hopeful method for the production of unchanging metallic nanoparticles in which could be utilized in various uses. Chemical-reduction technique has the features of existence appropriate and further economical than other techniques. Nanosized metal particles can be formed by reduction of dissolved metal salts such as nickel chloride using reduction agent such as hydrazine and straight metal phase precipitation from the solution in the presence of polyol solvents such as ethylene glycol (EC) as solvent [6]. 
In the previous work, pure Ni nanoparticles had been produced from both aqueous solution $[7,8]$ and pure organic solvent like EC [9] by means of hydrazine agent act as the reducing mediator at relatively high temperature. On the other hand, Kapoor, et al. [10] tested gamma radiolysis of nickel sulfate salt solution to prepare nickel nanoparticles.

This study investigates the preparation and characterization of different Ni nanoparticles by a modified chemical reduction method, preliminary from nickel chloride as raw material, hydrazine hydrate as reducing agent and polyvinylpyrrolidone (PVP) as shielding mediator in dilute aqueous solutions containing ethylene glycol and water as solvent.

\section{$\underline{\text { 2. Experimental work }}$}

\subsection{Chemicals}

Nickel chloride hexahydrate; $\mathrm{NiCl}_{2} \cdot 6 \mathrm{H}_{2} \mathrm{O}$ (analytical grade, Sigma-Aldrich), $80 \%$ Hydrazine hydrate; $\mathrm{N}_{2} \mathrm{H}_{4} \cdot \mathrm{H}_{2} \mathrm{O}$ (Merck), Ethylene glycol (Merck), Polyvinylpyrrolidone; PVP (Merck), $\mathrm{NaOH}$ (Merck) and ethanol were used as raw materials. All these chemicals were used without further purifications. Table (1) summarized the function of each material.

Table (1) Materials and there functions used for Ni nanoparticles preparation process

\begin{tabular}{|l|l|l|}
\hline Chemicals & Function & Purity, \% \\
\hline $\begin{array}{l}\text { Nickel chloride hexahydrate; } \\
\mathrm{NiCl}_{2} \cdot 6 \mathrm{H}_{2} \mathrm{O}\end{array}$ & Ni source & 99.9 \\
\hline Hydrazine hydrate; $\mathrm{N}_{2} \mathrm{H}_{4} \cdot \mathrm{H}_{2} \mathrm{O}$ & Reducing agent & 99.8 \\
\hline Ethylene glycol and water & Solvents & 99.6 \\
\hline Polyvinylpyrrolidone; PVP & protective agent & 99 \\
\hline $\mathrm{NaOH}$ & pH adjustment/catalyst & 99.98 \\
\hline Ethanol & Washing & 98 \\
\hline
\end{tabular}




\subsection{Methods}

Chemical reduction method was used for Nickel nanoparticles preparation. In one experiment, $1 \mathrm{~g}$ of nickel chloride hexahydrate and $1.0 \mathrm{~g}$ weight of Polyvinylpyrrolidone were added to $200 \mathrm{ml}$ ethylene glycol. $2 \mathrm{ml} \mathrm{N}_{2} \mathrm{H}_{4} \cdot \mathrm{H}_{2} \mathrm{O}$ was added into the solution (giving $\left[\mathrm{N}_{2} \mathrm{H}_{4}\right] /\left[\mathrm{NiCl}_{2}\right]$ mole ratio $\left.=15: 1\right)$ with continuous shaking using shaker with water path and kept in the thermostatic state at $80{ }^{\circ} \mathrm{C}$ and a blue solution was obtained. Then $2 \mathrm{ml}$ of 1 M sodium hydroxide was gradually dropped into the reaction mixture and the chemical reduction was allowable to continue for one hour. Latterly, black solids were formed and parted from the reaction suspension, washed several times using hot water and ethanol sequentially. Later, Ni nanoparticles were dried using electrical oven at $60{ }^{\circ} \mathrm{C}$ along 16 hour.

In another experiment, $2 \mathrm{~g}$ of nickel chloride hexahydrate and $4 \mathrm{~g}$ of polyvinylpyrrolidone were dissolved in $200 \mathrm{ml}$ ethylene glycol, $8 \mathrm{ml}$ hydrazine hydrate was added into the solution with shaking at $80{ }^{\circ} \mathrm{C}$ (giving $\left[\mathrm{N}_{2} \mathrm{H}_{4}\right] /\left[\mathrm{NiCl}_{2}\right]$ molar ratio of $30: 1$ ). $4 \mathrm{ml}$ of $1 \mathrm{M}$ $\mathrm{NaOH}$ was slowly added drop-wise into the above solution and the reaction was allowable to continue for one hour. When a black solution was formed, the resulted solids were washed carefully with hot water and ethanol, and then dried in an oven at $60{ }^{\circ} \mathrm{C}$ along 16 hour.

Another experiment includes the same above conditions of except using ethylene glycolwater mixture $(60 \%$ ethylene glycol) as solvent and the hydrazine to nickel chloride $\left(\left[\mathrm{N}_{2} \mathrm{H}_{4}\right] /\left[\mathrm{NiCl}_{2}\right]\right)$ molar ratio was set as $22: 1$. Fourth experiment includes using hydrazine to nickel chloride $\left(\left[\mathrm{N}_{2} \mathrm{H}_{4}\right] /\left[\mathrm{NiCl}_{2}\right]\right)$ molar ratio as $45: 1$. Table (2) summarized the reaction conditions of all experiments. In general Figure (1) summarized the procedure of nickel nanoparticles preparation. 
Table (2) Reaction conditions used for preparation of Ni nanoparticles.

\begin{tabular}{|c|c|c|c|c|}
\hline \multirow[t]{2}{*}{ Reaction parameters } & \multicolumn{4}{|c|}{ Exp. No. } \\
\hline & 1 & 2 & 3 & 4 \\
\hline Nickel chloride hexahydrate (g) & 1 & 2 & 2 & 2 \\
\hline Hydrazine hydrate $(\mathrm{ml})$ & 2 & 6 & 8 & 12 \\
\hline$\left[\mathrm{N}_{2} \mathrm{H}_{4}\right] /\left[\mathrm{NiCl}_{2}\right]$ molar ratio & $15: 1$ & $22: 1$ & $30: 1$ & $45: 1$ \\
\hline Polyvinylpyrrolidone PVP (g) & 1 & 4 & 4 & 4 \\
\hline$\left[\mathrm{PVP} / \mathrm{NiCl}_{2}\right]$ weight ratio & $1: 1$ & $2: 1$ & $2: 1$ & $2: 1$ \\
\hline Solvent $(200 \mathrm{ml})$ & EG & $\begin{array}{l}60 \% \text { EG- } \\
40 \% \text { water }\end{array}$ & EG & EG \\
\hline Temp. ${ }^{\circ} \mathrm{C}$ & 80 & 80 & 80 & 80 \\
\hline $1 \mathrm{M} \mathrm{NaOH}(\mathrm{ml})$ & 2 & 4 & 4 & 4 \\
\hline
\end{tabular}

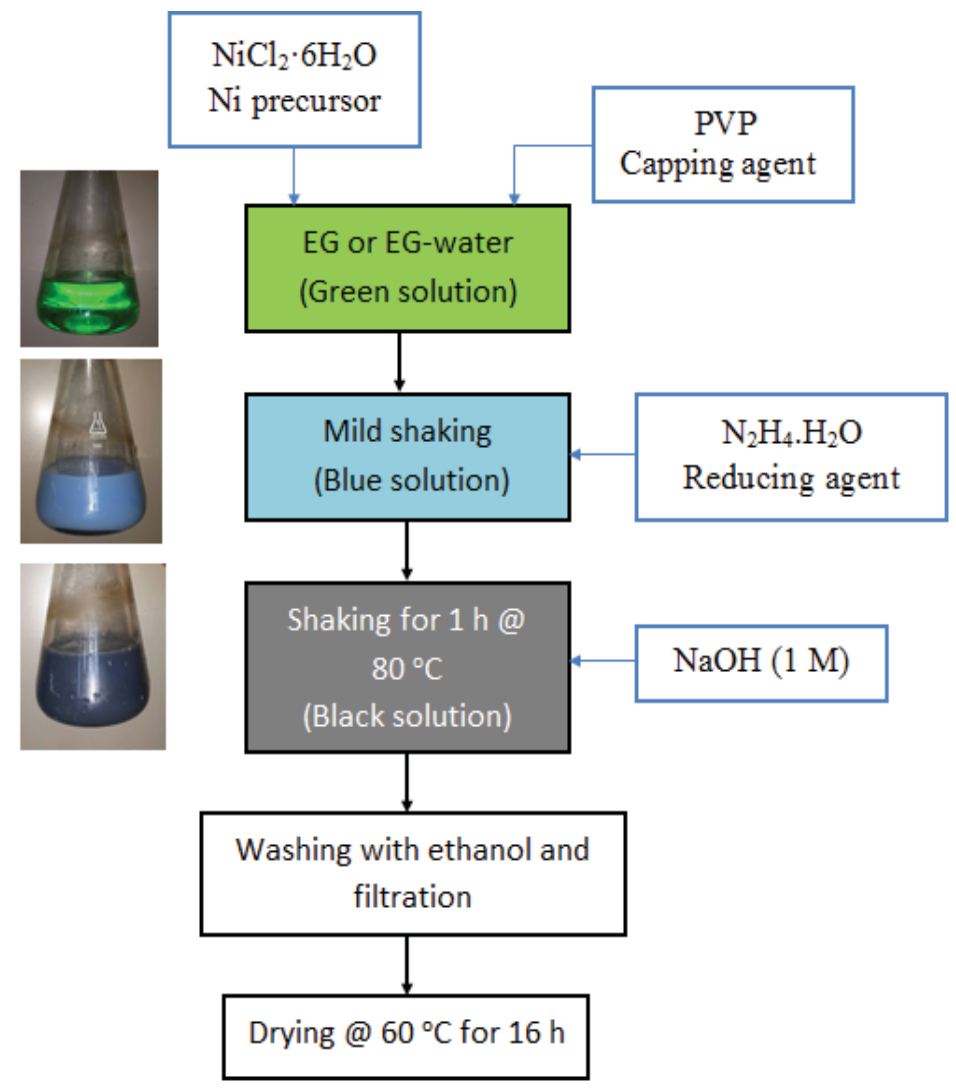

Fig. (1) General procedure for Ni nanoparticles preparation through chemicalreduction way. 
The resulted Ni nanoparticles were analyzed via powder XRD analysis (Rigaiku, D-Max $2000)$ by $\mathrm{Cu}-\mathrm{K} \alpha$ radioactivity through graphite monochromator. Atomic Force microscope (AFM) (JEEOL, 4500) was utilized to appearance the nanosize and morphological properties of the obtained Ni nano powders.

\section{$\underline{\text { 3. Results and Discussion }}$}

\subsection{Ni nanoparticles preparation}

According to the preliminary chemical reduction experiments (using pure ethylene glycol solvent), $\mathrm{Ni}$ ion were converted via hydrazine to nickel by the following reaction:

$$
2 \mathrm{Ni}^{+2}+\mathrm{N}_{2} \mathrm{H}_{4}+4 \mathrm{OH}^{-} \rightarrow 2 \mathrm{Ni}+\mathrm{N}_{2}+4 \mathrm{H}_{2} \mathrm{O}
$$

The temperature of the reaction was very cooperative in quickening the rate of reaction [11]. In this work, the temperature was constant at $80{ }^{\circ} \mathrm{C}$. According to the Hinotsu work, $\mathrm{N}_{2}$ gas bubbled up always throughout reaction, therefore, it is expected that no Ni oxides or hydroxide species like $\mathrm{NiO}$ or $\mathrm{Ni}_{2} \mathrm{O}_{3}$ were formed because $\mathrm{N}_{2}$ gas created an inert atmosphere.

Adding of trace sodium hydroxide base solution was necessary to increase the $\mathrm{pH}$ of the reaction mixture to $\geq 10.5$ in order to produce pure nickel nanoparticles [12]. It was suggested that the trace amount of $\mathrm{NaOH}$ solution might catalyzed the reaction not only $\mathrm{pH}$ adjustable. This is also what $\mathrm{Wu}$ and Cen, 2003 suggest who found that no $\mathrm{Ni}$ nanoparticles were produced if more hydrazine agent was used to raise the $\mathrm{pH}$ of the reaction mixture to 10.5 without $\mathrm{NaOH}$ addition [5].

The effect of $\left(\left[\mathrm{N}_{2} \mathrm{H}_{4}\right] /\left[\mathrm{NiCl}_{2}\right]\right)$ molar ratio on Ni particle size was demonstrated in Figure (2). It is seen that, with increasing $\left[\mathrm{N}_{2} \mathrm{H}_{4}\right] /\left[\mathrm{NiCl}_{2}\right]$ molar ratio, the nickel nanoparticles mean diameter decreased. The nickel chloride to hydrazine molar ratio affects the reduction rate and therefore on the nucleation. For low $\left[\mathrm{N}_{2} \mathrm{H}_{4}\right] /\left[\mathrm{NiCl}_{2}\right]$ molar ration, the 
reduction rate was slow and this leads to decrease the number of nickel nuclei made in the initial duration of reaction causing an increase in particle size [13, 14]. Increasing of $\left[\mathrm{N}_{2} \mathrm{H}_{4}\right] /\left[\mathrm{NiCl}_{2}\right]$ molar ration leads to enhance the rate of reduction preferred the formation of additional nuclei and therefore reduced size nickel nanoparticles.

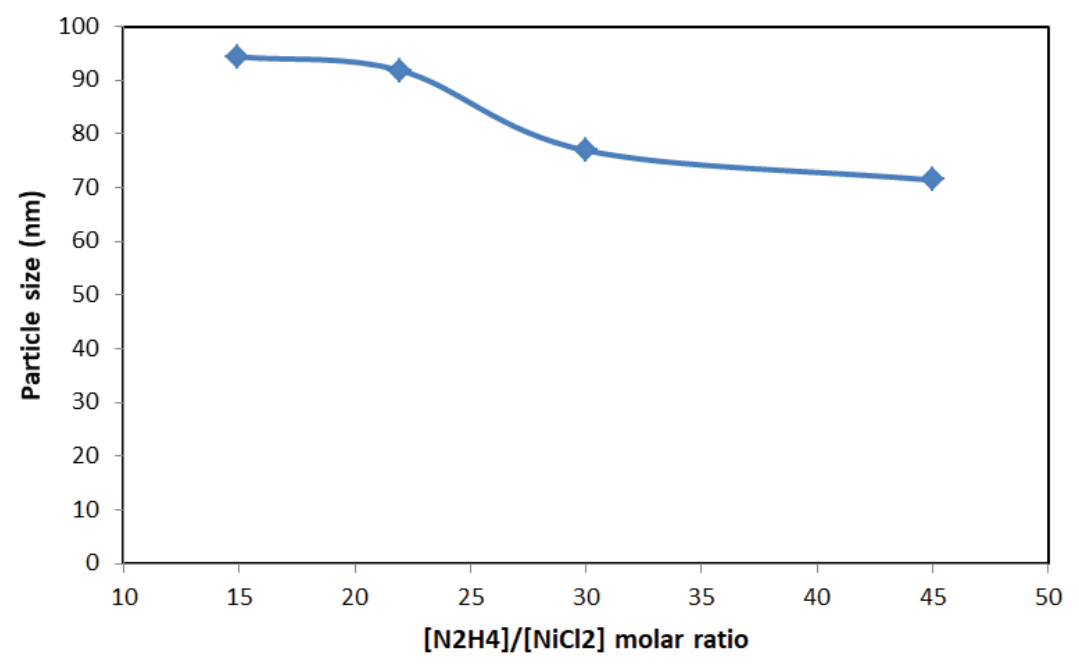

Fig. (2) Effect of $\left[\mathrm{N}_{2} \mathrm{H}_{4}\right] /\left[\mathrm{NiCl}_{2}\right]$ mole ratio on $\mathrm{Ni}$ particle size.

Also in present work, two different concentrations of the protective agent PVP were used as shown in Table (2) It can be seen that as the $\left[\mathrm{PVP} / \mathrm{NiCl}_{2}\right]$ weight ratio was increased the size of Ni particles obtained was decreased. Increasing PVP concentration in the reaction mixture leads to more stabilization of producing Ni nanoparticles. The PVP molecule contains a hydrophilic head and a hydrophobic tail and when the Ni nucleus is formed, more hydrophobic parts of PVP molecule gets connected to Ni nucleus and hence prevents Ni agglomeration [15].

In experiment No.2 (Table 2), the nickel nanoparticles were produced by using aqueous solution containing $60 \% \mathrm{EG}$ and $40 \%$ water. However, the data on the production of $\mathrm{Ni}$ colloids in aqueous solution was still infrequent. Results showed the particle size was not affected when using EG-water aqueous solutions compared with pure EG. 


\subsection{Characterization}

XRD diffractogram of the prepared Ni nanoparticles is revealed in Figure 3. The crystal structure was determined in a $2 \theta$ range of $20-80^{\circ}$. The peak $2 \theta=44.59^{\circ}, 52$ and 76.45 which synchronize with the 111,200 , and 220 phases of pure $\mathrm{Ni}$, (conferring to the normal PDF card Number 04-0850). These characteristic peaks suggest that the resulted nanoparticles were pure Ni nanoparticles without considerable oxides or other impurity phases (without any other additional peaks). For comparison purpose, Figure 4 displays the XRD diffractogram shape of standard Ni nanoparticles. The solid crystal purity was dignified by comparing the XRD diffractogram shape of prepared Ni nanoparticles with XRD diffractogram form of typical Ni nanoparticles. This comparison proved that the prepared Ni nanoparticles were matching the standard.

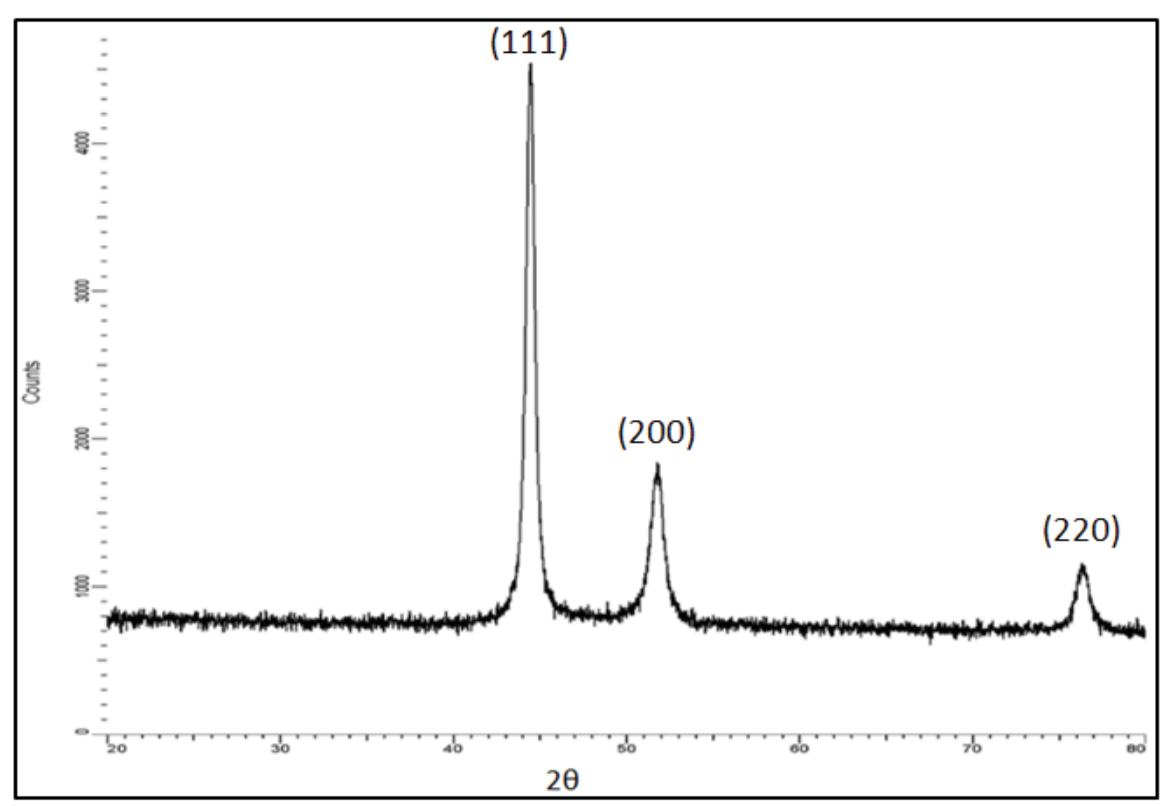

Fig. (3) Powder XRD diffraction spectrum of Ni nanoparticles $\left(\left[\mathrm{N}_{2} \mathrm{H}_{4}\right] /\left[\mathrm{NiCl}_{2}\right]\right.$ molar ratio $=15: 1,\left[\mathrm{PVP} / \mathrm{NiCl}_{2}\right]$ weight ratio $=1: 1$, solvent $\left.=\mathrm{EG}\right)$ 


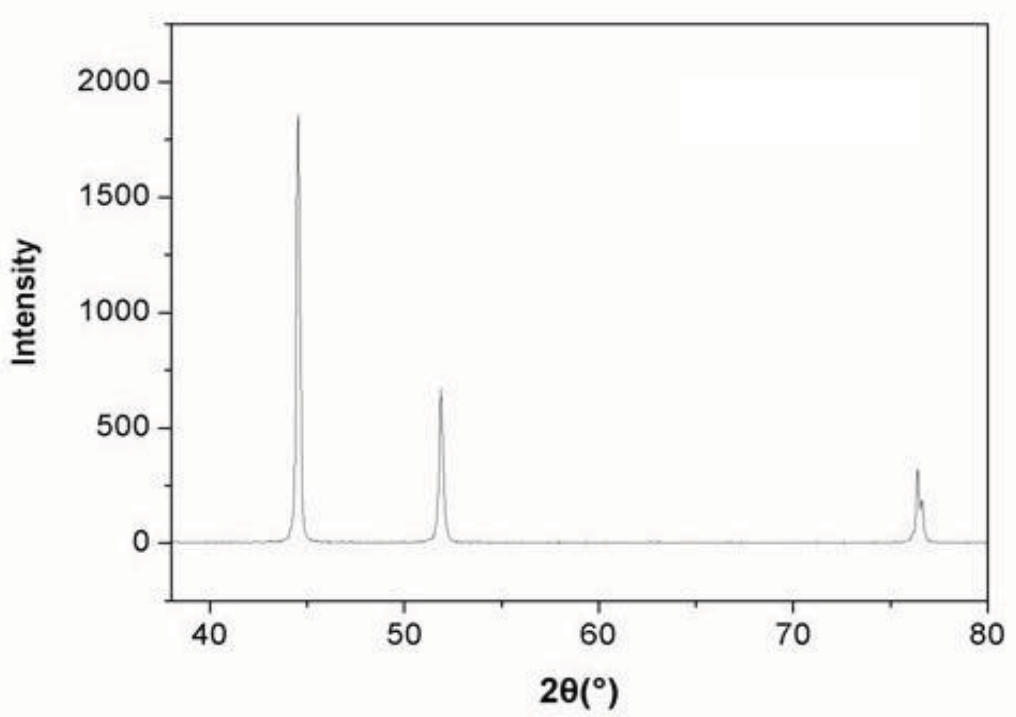

Fig. (4) XRD diffraction pattern of typical (standard) Ni nanoparticles.

Figures (5-a), (5-b), (5-c) and (5-d) display the images of AFM on two- and threedimensional surface profile at different $\left[\mathrm{N}_{2} \mathrm{H}_{4}\right] /\left[\mathrm{NiCl}_{2}\right]$ molar ratios. The two dimensional surface AFM images show an irregular spherical structure of the Ni particles. Three dimensional surfaces indicate that the agglomerates of $\mathrm{Ni}$ nano crystal are in form of irregular spherical and rough shape with average roughness from 2.11 to $0.89 \mathrm{~nm}$. Figures (6-a), (6-b), (6-c) and (6-d) display the granularity cumulation distribution charts at $\left[\mathrm{N}_{2} \mathrm{H}_{4}\right] /\left[\mathrm{NiCl}_{2}\right]$ molar ratio of $15: 1,22: 1,30: 1$ and $45: 1$. As shown in these figures, the particle size distributions confirmed that all Ni nanoparticle samples essentially were fine and revealed nanosized nickel particles with a mea diameter ranges from 94.3 to $71.48 \mathrm{~nm}$ within the $\left[\mathrm{N}_{2} \mathrm{H}_{4}\right] /\left[\mathrm{NiCl}_{2}\right]$ molar ratios studied (15:1 to $\left.45: 1\right)$. 
$\mathbf{a}$
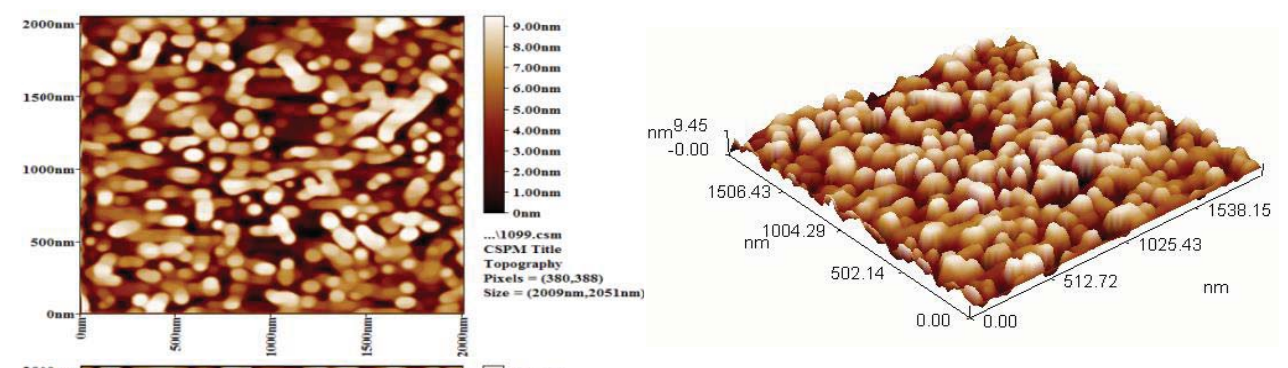

b
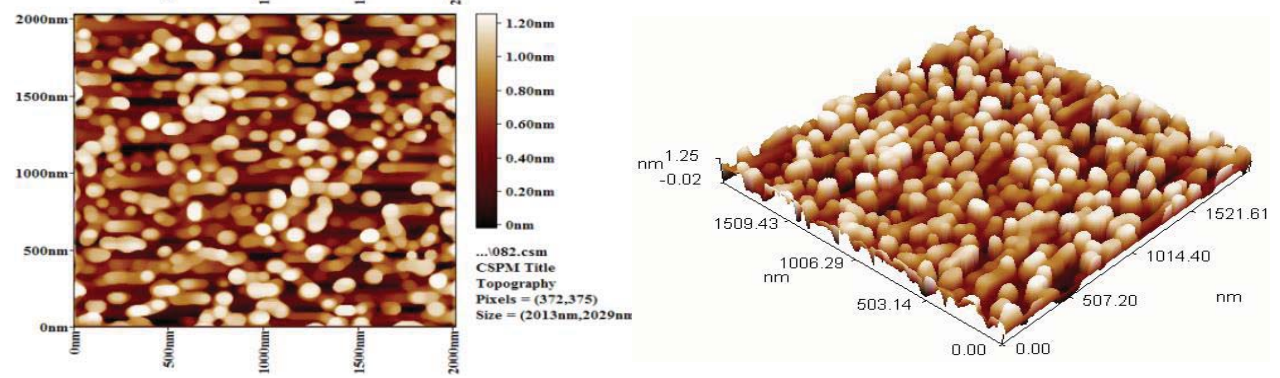

c
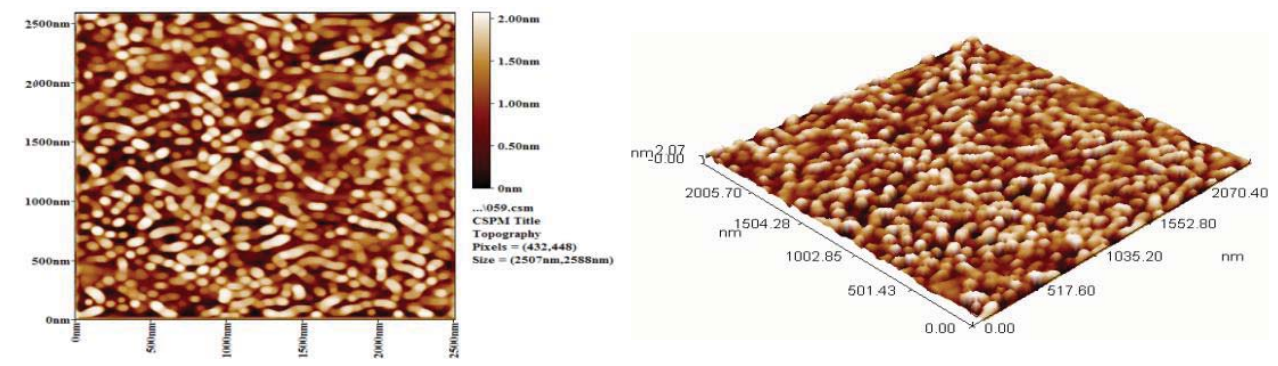

d
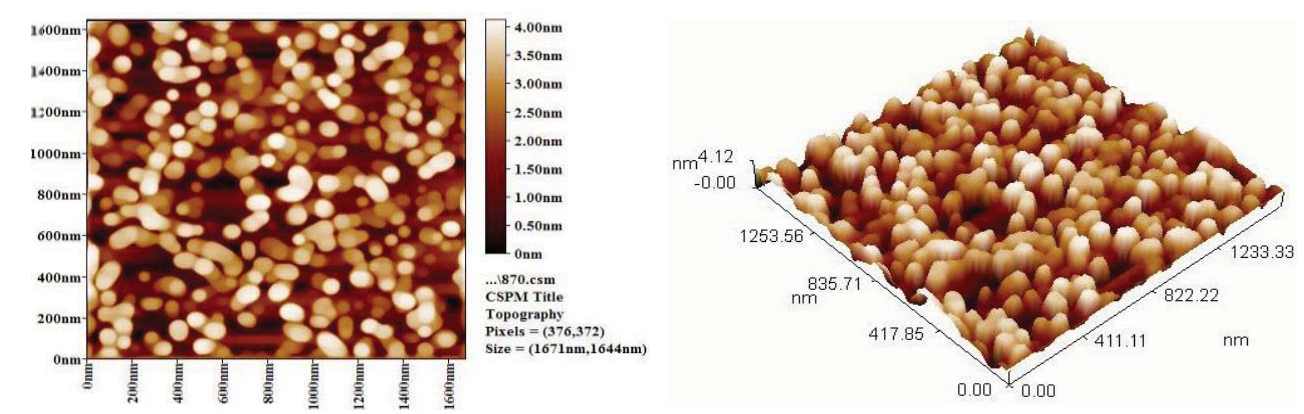

Fig. (5) AFM on two and three dimensional surface of prepared Ni nanoparticles for

$\left[\mathrm{N}_{2} \mathrm{H}_{4}\right] /\left[\mathrm{NiCl}_{2}\right]$ molar ratio of (a) 15:1 (Avg. diameter: $94.35 \mathrm{~nm}$ ), (b) 22:1 (Avg. diameter: $91.78 \mathrm{~nm}$, (c) 30:1 (Avg. diameter: 76.93 nm) and (d) 45:1 (Avg. diameter: $71.48 \mathrm{~nm})$. 

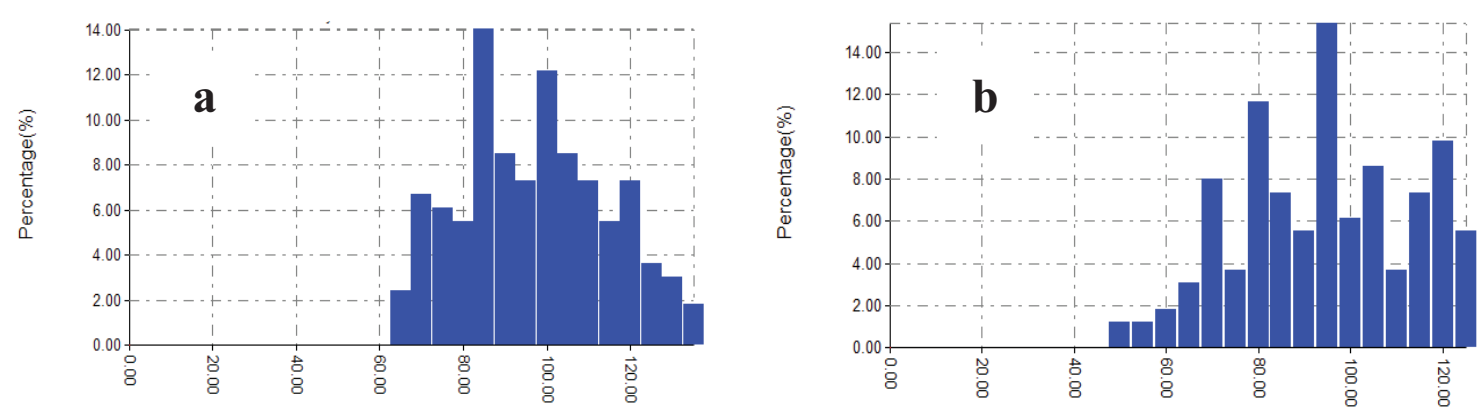

Diameter(nm)

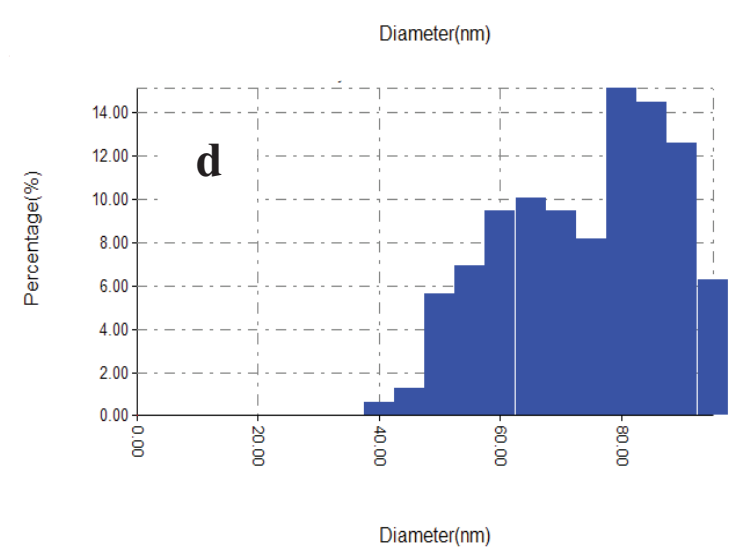

Fig. (6) Bar chart of particle size distribution for prepared Ni nanoparticles at $\left[\mathrm{N}_{2} \mathrm{H}_{4}\right] /\left[\mathrm{NiCl}_{2}\right]$ molar ratio of (a) 15:1 (Avg. diameter: $94.35 \mathrm{~nm}$ ), (b) 22:1 (Avg. diameter: $91.78 \mathrm{~nm}$, (c) 30:1 (Avg. diameter: 76.93 nm) and (d) 45:1 (Avg. diameter: $71.48 \mathrm{~nm})$.

\section{Conclusions}

Nickel nanoparticles were synthesized via hydrazine hydrate as reducing mediator in ethylene glycol aqueous solutions and also in pure ethylene glycol medium using polyvinylpyrrolidone as protective agent. Pure nickel nanoparticles have been successfully prepared by this route. Nickel nanoparticles size were found to be depended on the $\left[\mathrm{N}_{2} \mathrm{H}_{4}\right] /\left[\mathrm{Ni}^{2+}\right]$ molar ratio which studied from $15: 1$ to $45: 1$. Particle size increases from $94.35 \mathrm{~nm}$ to $71.48 \mathrm{~nm}$ when increases the $\left[\mathrm{N}_{2} \mathrm{H}_{4}\right] /\left[\mathrm{Ni}^{2+}\right]$ molar ratio from $15: 1$ to $45: 1$. 


\section{5. $\underline{\text { References }}$}

1. Wu, X., Xing, W., Zhang, L., Zhuo, S., Zhou, J., Wang, G., \& Qiao, S. (2012). Nickel nanoparticles prepared by hydrazine hydrate reduction and their application in supercapacitor. Powder technology, 224, 162-167.

2. Park, J. W., Chae, E. H., Kim, S. H., Lee, J. H., Kim, J. W., Yoon, S. M., \& Choi, J. Y. (2006). Preparation of fine Ni powders from nickel hydrazine complex. Materials Chemistry and Physics, 97(2), 371-378.

3. Tientong, J., Garcia, S., Thurber, C. R., \& Golden, T. D. (2014). Synthesis of nickel and nickel hydroxide nanopowders by simplified chemical reduction. Journal of Nanotechnology, 2014.

4. Couto, G. G., Klein, J. J., Schreiner, W. H., Mosca, D. H., de Oliveira, A. J., \& Zarbin, A. J. (2007). Nickel nanoparticles obtained by a modified polyol process: synthesis, characterization, and magnetic properties. Journal of colloid and Interface science, 311(2), 461-468.

5. Wu, S. H., \& Chen, D. H. (2003). Synthesis and characterization of nickel nanoparticles by hydrazine reduction in ethylene glycol. Journal of Colloid and Interface Science, 259(2), 282-286.

6. Sugimoto, T. (Ed.). (2000). Fine particles: synthesis, characterization, and mechanisms of growth (Vol. 92). CRC Press.

7. Chou K. S. and K. C. Huang, "Studies on the Chemical Synthesis of Nanosized Nickel Powder and Its Stability”, J. Nanoparticle Res., 3 (2001) 127-132.

8. Li Y. D., C. W. Li, H. R. Wang, L. Q. Li and Y. T. Qian, "Preparation of Nickel Ultrafine Powder and Crystalline Film by Chemical Control Reduction", Mater. Chem. Phys., 59 (1999) 88-90.

9. Zhang FB, YT Chen, JZ Zhao and HL Li, "Preparation of Nanosized Nickel by Hydrothermal Method", Chemistry Lett., 33 [2] (2004) 146-147.

10. Kapoor, S. HG Salunke, AK Tripathi, SK Kulshreshtha and JP Mittal, "Radiolytic Preparation and Catalytic Properties of Nanophase Nickel Metal Particles", Mater. Res. Bull., 35 [1] (2000) 143-148. 
11. Hinotsu, T., Jeyadevan, B., Chinnasamy, C. N., Shinoda, K., \& Tohji, K. (2004). Size and structure control of magnetic nanoparticles by using a modified polyol process. Journal of applied physics, 95(11), 7477-7479.

12. Pandey, A., \& Manivannan, R. (2015). Chemical reduction technique for the synthesis of nickel nanoparticles. Int. Journal of Engineering Research and Applications, Vol. 5, Issue 4, ( Part -2) April 2015, pp.96-100.

13. Huang, G. Y., Xu, S. M., Gang, X. U., Li, L. Y., \& Zhang, L. F. (2009). Preparation of fine nickel powders via reduction of nickel hydrazine complex precursors. Transactions of Nonferrous Metals Society of China, 19(2), 389-393.

14. Wang, H., Kou, X., Zhang, L., \& Li, J. (2008). Size-controlled synthesis, microstructure and magnetic properties of $\mathrm{Ni}$ nanoparticles. Materials Research Bulletin, 43(12), 3529-3536.

15. Gao, J., Guan, F., Zhao, Y., Yang, W., Ma, Y., Lu, X., \& Kang, J. (2001). Preparation of ultrafine nickel powder and its catalytic dehydrogenation activity. Materials Chemistry and Physics, 71(2), 215-219.

تحضير وتثخيص جسيمات النيكل المغناطيسية النانوية بواسطة تقاعل الاختز ال الكيميائي د. سعد حنش عمار، نذير نوري اسماعيل، د. مروة فائق عبدالجبار

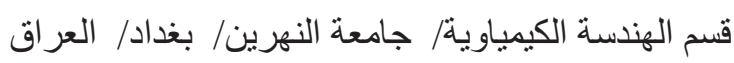

الخلاصة

ان كفاءة العديد من العمليات التحويلية في الصناعة البترولية تتحسن عند استخدام المواد ذات البعد المقياس النانوي، و الذي يحدث بسبب التحسينات والتطورات في الخصائص المحسنة مع انخفاض ع حجم الجسيمات .جسيمات النيكل النانوية لديها العديد من التطبيقات في صناعة البترول كعامل مساعد بالإضافة إلى الخصائص المغناطيسية. تم في هذا البحث تحضير جسيمات النيكل النانوية النقية بنجاح بواسطة تفاعل الاختزال الكيميائي لكلوريد النيكل باستخدام الهيدرزين المائي كعامل مخنزل في المحاليل المائية للاتلين كلايكول كمذيب وباستخدام بولمر البولي فينيل بايروليدون كمادة مانعة لتكتل الجسيمات. ايضا استخدمت عدة تراكيز من مادة هيدروكسيد الصوديوم لزيادة الرقم الهيدروجيني 
لخليط التفاعل بالاظافة لخو اصها الحفازية والمسر عة للتفاعل. تم الحصول على عدة نماذج لجسيمات النيكل النانوية عند استخدام عدة نسب تفاعل مولية للهيدرزين/كلوريد النيكل وبدرجة حر ارة ثابتة (80) م). تم تشخيص الخواص البنائية والثكلية لجسمات النيكل النانوية المحضرة باستخدام جهاز قياس حيود الاشعة السينية (XRD) وجهاز مجهر القوة الذرية (AFM). اظهرت النتائج الحصول على (A) مسحوق نيكل نانوي نقي وان الحجم الحبيبي يتأثز كثير ا بنسبة الهيدرازين/كلوريد النيكل المولية حيث ينخفض الحجم الحبيبي لجسيمات النيكل المحضرة من 94,35 الى 71,48 نانومتر عند زيادة نسبة الهيدرزين/كلوريد النيكل المولية من 15:1 الى 45:1. 